\title{
SEKULARISASI DALAM PANDANGAN HARVEY COX
}

\author{
Fauzan \\ IAIN Raden Intan Lampung \\ Email: fauzan@iainradenintan.ac.id
}

\begin{abstract}
Abstrak
Sebagian besar kaum agamawan (ortodoks) memandang sekularisasi sebagai ancaman terhadap eksistensi agama. Namun sebaliknya, Harvey Cox memandang sekularisasi sebagai teologi perubahan sosial yang bertujuan mendobrak kebuntuan agama yang terbelenggu oleh ide "pemeliharaan" dan "kemapanan". Tulisan ini membahas pandangan Harvey Cox tentang sekularisasi, konsepnya tentang Kota Sekuler (Secular City), dan Tuhan pada masyarakat sekuler. Cox melihat sekularisasi merupakan sebuah keniscayaan sejarah. Sekularisasi merupakan gerakan yang membebaskan manusia dari dogma yang membelenggu kebebasan manusia. Melalui simbol Kota Sekuler, Cox menghadirkan paradigma teologi yang lebih sesuai dengan keadaan masyarakat modern saat ini. Cox melihat bahwa Tuhan sebagaimana yang diajarkan oleh Kristiani -juga agama lain- bukanlah Tuhan yang sebenarnya. Tuhan tak lebih dari sebuah penamaan yang kehadirannya terkadang kosong dan ambigu. Semenjak penamaan dilekatkan dalam lingkungan sosio kultural tertentu, maka kata "Tuhan" tidak suci lagi. Apabila Tuhan dimaknai secara "ketat" dalam ruang tradisi yang berbeda-beda, maka akan terjadi benturan yang terkadang membutuhkan pengorbanan jiwa.
\end{abstract}

Abstract

SECULARISM IN VIEW HARVEY COX. Most of the orthodox clergy sees secularization as a threat to the existence of religion. Instead, Harvey Cox sees secularization as a theology of social change that aims to break the deadlock religion captivated by the idea of "maintenance" and "establishment". This paper discusses the views of Harvey Cox of secularization, the concept of the Secular City (Secular City), and God in a secular society. Cox saw secularization is a historical inevitability. 
Secularization is a movement to liberate mankind from the shackles of dogma that human freedom. Through symbol Secular City, Cox brings theological paradigm is more appropriate to the circumstances of today's modern society. Cox saw that God as taught by the Christian religion-also etc. God is not real. God is nothing more than a naming whose presence is sometimes empty and ambiguous. Since naming embedded in specific socio-cultural environment, the word "God" is not sacred anymore. If God is defined "tightly" in the space of different traditions, there will be a crash that sometimes requires sacrifice of life.

Kata Kunci: sekularisasi; sekuler; Tuhan; sosial.

\section{A. Pendahuluan}

"Pada mulanya, manusia menciptakan satu Tuhan yang merupakan penyebab pertama bagi segala sesuatu dan penguasa langit dan bumi. Perlahan-lahan dia memudar dari kesadaran umatnya. Dia telah menjadi begitu jauh sehingga mereka memutuskan bahwa mereka tidak lagi menginginkannya. Pada akhirnya Dia telah dikatakan menghilang."1 Penuturan Wilhelm Schmidt tersebut sengaja penulis ungkapkan diawal kata, untuk memberikan gambaran umum bahwa keyakinan manusia terhadap Zat yang Ultimat, adikodrati, berjalan ke arah yang berseberangan dengan apa yang diinginkan oleh agama itu sendiri. Secara formal, boleh jadi, setiap umat yang beragama (Islam, Kristen, Katolik, Budha, Hindu, dll) masih mengakui eksistensi Tuhan tersebut. Akan tetapi dalam praksis kehidupan sosial, konsepsi Tuhan yang Maha Kuasa tersebut secara perlahan namun pasti mengalami pengkaburan di tengah-tengah kompleksitas persoalan yang dihadapi manusia modern. Tuhan yang awalnya begitu nyata dengan segala "personality"nya, semakin terpinggirkan oleh segala kepentingan "positivistik" manusia. Pada gilirannya, kata "Tuhan" tidak lagi bermakna, hanya menjadi simbol kosong yang tak berisi “eksistensi ultimate' lagi. Bahkan desakan kepentingan manusia modern memaksa manusia untuk bersikap acuh dan tidak membutuhkannya lagi.

${ }^{1}$ Dikutip dari Karen Amstrong, Sejarah Tuhan, terj, (Bandung: Mizan, 2001), h. 27. 
Renaisance $^{2}$ yang terjadi di Barat menjelang akhir abad ke 16, secara alamiah telah mempengaruhi cara manusia dalam mempersepsi diri dan mendorong mereka untuk meninjau kembali hubungannya dengan Realitas Tertinggi (Ultimate Reality) yang biasa disebut Tuhan. Perubahan orientasi yang terjadi pada masa ini berdampak amat luas dan mendalam. Di satu pihak manusia telah memiliki kembali otonomi beserta segala kebebasannya, dan di pihak lain manusia kemudian mengarahkan hidupnya pada dunia sekuler. ${ }^{3}$ Sebagai implikasinya, semangat otonomi dan independensi baru itu mendorong sebagian orang untuk mendeklarasikan kebebasan dirinya dari Tuhan. Gagasan semacam itu nampak jelas dalam pemikiran beberapa tokoh semacam August Comte, Emile Durkheim, Max Weber, Herbert Spencer, Ludwig Feuerbach, Karl Marx, Charles Darwin, Friederich Nietzche, dan Sigmund Frued.

Para pemikir sosial terkemuka abad ke-19 tersebut yakin bahwa agama perlahan-lahan akan pudar dan tidak begitu penting perannya bersamaan dengan makin majunya masyarakat industri. Mereka berusaha menyusun tafsiran filosofis dan ilmiah tentang realitas tanpa menyisakan tempat bagi Tuhan. Bahkan pada akhir abad itu, sebagian orang mulai merasakan sekiranya Tuhan belum mati, maka adalah tugas manusia yang rasional dan teremansipasi untuk membunuhnya. ${ }^{4}$ Gagasan ini sekaligus mengukuhkan sebuah teologi baru (abad modern); yaitu teologi "Tuhan Mati" 5 yang lebih menekankan karakteristik desakralisasi dan sekularisasi sebagai corak keberagamaannya.

${ }^{2}$ Renaizance merupakan babak baru di mana berbagai tata nilai - baik yang berkaitan dengan keagamaan, politik maupun kenegaraan - yang ada mulai diuji. Zaman ini ditandai dengan berkembangnya filsafat sosial dan politik, reorientasi filsafat tentang kemanusiaan, dan perkembangan ilmu beserta percabangannya dalam berbagai disiplin. Lihat Fuad Hassan, Pengantar Filsafat Barat, (Jakarta: Dunia Pustaka, 1996), h. $69-71$.

${ }^{3}$ Koento Wibisono Siswomihardjo, Пmu Pengetahuan: Sebuah Sketsa Ilmu Mengenai Kelahiran dan Perkembangannya Sebagai Pengantar Untuk Memahami Filsafat Пmu, Diktat Kuliah Filsafat Ilmu, Tidak diterbitkan, h. 4

${ }^{4}$ Karen Amstrong, Sejarah ... h. 446.

${ }^{5}$ Gagasan tentang kematian Tuhan pertama kali dikumandangkan oleh Friederich Nietzche dalam suatu bagian bukunya yang berjudul Die Fronhliche Wissenschaft, yang ditulisnya pada tahun 1882. Dalam Harun Hadiwijono, Teologi Reformatoris Abad ke-20, (Jakarta: Gubug Mulia, 1993), h. 154. 
Dalam paradigma semacam itu, pada era tahun 60-an muncul pemikiran tentang sekularisasi, sebagaimana ditampilkan oleh Paul Van Buren (1963), dalam tulisannya yang berjudul The Secular Meaning of The Gospel. Selain itu, salah satu pemikir yang cukup menonjol dalam bidang ini adalah Hervey Cox yang telah mencetuskan gagasannya tentang sekularisasi dalam bukunya yang berjudul The Secular City pada tahun 1965. Tulisan berikut akan mencoba memotret (1) bagaimana sebenarnya sekularisasi dalam pandangan Harvey Cox. Lalu bagaimana mainstream pemikirannya tentang Kota Sekuler (Secular City), dan (3) bagaimana gambaran Tuhan pada masyarakat sekuler.

\section{B. Biografi Singkat Harvey Cox, Jr}

Harvey Cox, Jr lahir pada tahun 1929 di Malvern, Pensylvania. ${ }^{6}$ Semasa kecil ia menempuh pendidikan dasar dikota kelahirannya tersebut. Pada saat terjadi Perang Dunia ke-2, Cox mengikuti armada marinir dalam misi pertolongan yang membawa bahan makanan ke Eropa. Selanjutnya memasuki universitas Pennsylvania dan memperoleh gelar sarjana muda dalam bidang sejarah pada tahun 1951.

Gelar pertama dalam bidang teologi diperolehnya dari Yale Divinity School pada tahun 1955. Dan setahun kemudian (1956) ia diangkat menjadi pejabat Baptis Amerika. Ia ditempatkan sebagai seorang pendeta Protestan pada Universitas Temple dan direktur aktivitas keagamaan di perguruan tinggi Oberlin. Di awal tahun 60-an, ia mengambil program doktoral dalam bidang sejarah dan filsafat di Universitas Harvard. Sambil berusaha mendapatkan gelar Ph.D-nya, ia melayani American Baptist Home Mission Society dan mengajar paruh waktu pada Andover Newton Theological School. Akhirnya ia bergabung pada Harvard Divinity School pada tahun 1965.

Fokus kajian dan pengajarannya adalah masalah urbanisasi, pengembangan agama pada dunia Kristiani, dan pendeta geraja secara umum, khususnya Amerika Latin. Dia juga merupakan

\footnotetext{
${ }^{6}$ Lexicon Universal Encyclopedia, (New York: Lexicon Publication, 1990),
} h. 322 . 
professor tamu pada Brandeis University; Seminario Bautista de Mexico; Naropa Institut; dan University of Michigan.

Harvey Cox telah menyusun beberapa buku yang cukup terkenal, antara lain: The Secular City (1965); The Feast of Fool (1969); The Seduction of The Spirit (1973); Religion in The Secular City (1984); The Silencing of Leonardo Boff: Liberation Theology and The Future of World Cristianity; Many Mansions: A Cristian's Encounters With Other Faith (1988), Fire From Heaven: The Rise of Pentecostal Spirituality and The Reshaping of Religion in Twenty-First Century (1994).

\section{Sekilas Tentang Sekularisasi}

Menurut istilah, kata sekular berasal dari bahasa latin saeculum, yang memiliki arti dengan dua konotasi; waktu dan lokasi. Waktu menunjukkan pengertian "sekarang" atau "kini, dan lokasi merujuk pada pengertian "dunia". Jadi saeculum berarti zaman ini atau kekinian yang merujuk pada "peristiwa kekinian".7 Dengan pengertian demikian tersirat makna sebagai faham relatifitas dibangun oleh konteks eksistensi dunia yang selalu berubah. ${ }^{8}$

Dalam pandangan Peter L. Berger, sekularisasi dipahami sebagai "proses seluruh sektor-sektor kehidupan dalam masyarakat dan kebudayaan dilepaskan dari dominasi lembaga-lembaga dan simbol-simbolkeagamaan".Diabertanya,proses-prosesdankelompokkelompok sosio-kultural mana yang telah berfungsi sebagai saranasarana atau mediator-mediator bagi terjadinya sekularisasi. Dia mencatat berbagai macam faktor sebagai pendorong sekularisasi, antara lain: peradaban manusia sebagai suatu keseluruhan yang menyebar keseluruh dunia; dinamika yang ditimbulkan oleh kapitalisme industrial; gaya hidup yang ditimbulkan oleh produksi industrial; pengaruh dari ilmu pengetahuan modern yang meresap ke berbagai sektor kehidupan sosial; infrastruktur praktikal di dalam kehidupan sosial. ${ }^{9}$

${ }^{7}$ Ibid., h. 51

${ }^{8}$ Syed Muhammad an-Naquib al-Attas, Islam dan Sekularisme, (Bandung: Penerbit Pustaka, 1981), h. 19

${ }^{9}$ Disarikan dari Peter L. Berger, The Sacred Canopy: Elements of a Sociological Theory of Religion (New York: Doubleday \& Company, 1969), h. 109-125. Gagasan bahwa bangkitnya suatu pandangan dunia rasional telah merongrong fondasi iman kepada suatu dunia adikodrati, hal-hal yang misterius, dan magi, sangat kuat dipengaruhi 
Lebih lanjut Berger menjelaskan bahwa dari banyak faktor, faktor yang merupakan akar dan benih sekularisasi adalah tradisi keagamaan Barat, khususnya tradisi keagamaan biblis Yudaisme yang melalui kekristenan, khususnya tradisi Kristen Reformatoris Kalvinis, telah menjadi fondasi-fondasi peradaban modern. Berger menegaskan, dunia modern, dengan sekularisasinya, dapat ditafsirkan sebagai "suatu realisasi dari roh Kristen" dan "Protestantisme telah memainkan suatu peran khas di dalam menegakkan dunia modern." 10

Kontras dengan Gereja Roma Katolik yang kehidupan praktis dan ritual keagamaannya masih dipenuhi aura kekeramatan dan pesona magis dunia transendental, kehidupan Gereja Protestan Kalvinis telah mengalami "disenchantment of the world" (Entzauberung der Welt), telah "kehilangan kekeramatan (atau pesona magis) dunia ini”; orang-orang Prostestan tinggal di dalam suatu dunia yang numinositas-nya telah diambil darinya, dunia yang "bereft of numinosity". Tidak ada malaikat-malaikat, tidak ada orang-orang kudus dan Bunda Maria sebagai perantara-perantara keselamatan, tidak ada roti dan anggur yang berubah menjadi daging dan darah Kristus, ${ }^{11}$

Bagi orang Protestan Kalvinis, Allah begitu tinggi, jauh di atas sana, transenden, suci tidak tertandingi oleh siapapun dan apapun yang ada di dalam dunia. Sebaliknya, manusia, dalam kaca mata orang Protestan Kalvinis, adalah makhluk fana dan hina yang telah jatuh ke dalam dosa, makhluk pendosa, dan karena itu terpisah dan terputus sama sekali dari Allah yang Maha Suci dan transenden. Hanya ada ada satu penghubung antara Allah dan manusia, yakni firman Allah, dalam arti firman yang menyatakan bahwa pemulihan hubungan (antara Allah dan manusia) hanya mungkin terjadi karena "rakhmat semata-mata," sola gratia (seperti menjadi pengakuan iman Protestan Lutheran). Ketika penghubung satu-satunya ini

oleh Max Weber melalui tulisannya, The Protestant Ethic and the Spirit of Capitalism. Diterjemahkan oleh T. Parsons (New York: Scribner's, 1930]; London \& New York: Routledge Classics, 2001, cetak ulang 2006, dengan introduksi dari Anthony Giddens). Lihat juga bukunya yang berjudul, The Sociology of Religion (Boston: Beacon Press, 1993).

\footnotetext{
${ }^{10}$ Ibid.

${ }^{11}$ Ibid.
} 
dipatahkan, karena sudah tidak "plausible" (tidak masuk akal) lagi, maka terpisahlah dunia imanen dari dunia transenden selamalamanya; maka, dunia kodrati sungguh-sungguh telah "bereft of numinosum" dan menjadi realitas empiris duniawi semata-mata, "God is dead". Ketika ini terjadi, maka realitas empiris ini menjadi terbuka terhadap penetrasi rasional dan sistematik, baik dalam pemikiran maupun dalam aktivitas, yang kita hubungkan dengan sains modern dan teknologi. Langit kini kosong tanpa malaikat, terbuka untuk diintervensi oleh para astronom, dan akhirnya, oleh para astronot. Maka, proses sekularisasi pun dimulailah. ${ }^{12}$

Berger menandaskan, pandangan bahwa dunia ini sudah kehilangan pesona magis dan kekeramatannya, karena mengalami desakralisasi dan demitologisasi, telah tersekularisasi, sudah dimulai dalam Perjanjian Lama, kitab suci agama Yahudi, agama yang dipenuhi oleh motif-motif transendentalisasi (Allah itu Esa, di atas sana, tidak terjangkau), historisasi (namun, Allah yang adikodrati itu, bekerja dalam sejarah Israel, menuntut respons umat, dan membuat ikatan perjanjian, berith, dengannya) dan rasionalisasi etika (anti-magis: umat diperkenan Allah bukan karena melakukan praktek-praktek magis, tetapi karena melaksanakan Taurat Allah). yang semuanya menghubungkan dunia imanen (dunia kodrati) dengan dunia transendental (dunia adikodrati) di mana Allah berada. ${ }^{13}$

Tokoh lain yang memberikan perhatian terhadap sekularisasi adalah Karel Dobbelaere. Menurutnya sekularisasi adalah suatu proses dalam masyarakat di dalam mana suatu sistem keagamaan yang transenden dan mencakup segalanya disusutkan menjadi suatu subsistem dari masyarakat yang ada bersama subsistem-subsistem lainnya; proses ini membuat klaimklaim agama tentang pencakupan segalanya di dalam dirinya kehilangan relevansinya. Dengan demikian, lembaga agama termarjinalisasi dan terprivatisasi. ${ }^{14}$

${ }^{12}$ Ibid.

${ }^{13}$ Ibid.

${ }^{14}$ Karel Dobbelaere, "The Secularization of Society? Some Methodological Suggestions”, dalam Jeffrey K. Hadden \& Anson Shupe (eds.), Secularization and Fundamentalism Reconsidered: Religion and the Political Order, (New York: Paragon House, 1989), h. 27-44. Pendapat bahwa diferensiasi fungsional telah melahirkan 
Dobbelaere berteori bahwa sekularisasi terjadi karena di dalam masyarakat telah berlangsung perubahan-perubahan struktural, yang membuat sistem besar pengelolaan atau manajemen masyarakat disubdivisikan ke dalam subsistem-subsistem yang lebih kecil namun rasional, yang masing-masing memainkan fungsi sendiri-sendiri (ekonomi, polity, famili, pendidikan, sains). Subsistem-subsistem ini berfungsi dengan sangat terspesialisasi dan terdiferensiasi, dan keadaan ini menghasilkan organisasi-organisasi yang makin bertambah rasional. Masyarakat menjadi tersegmentasi ke dalam sejumlah domain kelembagaan, yang fungsional, rasional dan otonom. Subdivisi-subdivisi, diferensiasi, segmentasi, spesialisasi dan individuasi fungsi-fungsi dalam masyarakat hanya bisa berlangsung kalau ada nilai-nilai civik inti yang melandasi dan menyemangati, yakni libertas dan equalitas. Tetapi karena tidak semua orang memiliki keahlian-keahlian yang diperlukan (meskipun ada nilai equalitas), maka di dalam subsistem-subsistem itu diperlukan orang-orang yang profesional. Siapa saja yang memiliki profesionalitas, boleh berfungsi dalam suatu subsistem yang cocok.

Dobbelaere menandaskan, "karena itu, kita dapat berbicara mengenai sekularisasi hanya di dalam masyarakat yang di dalamnya suatu proses diferensiasi telah dijalankan untuk memisahkan beberapa domain kelembagaan, misalnya, domain politik dari domain agama." Katanya lagi, "semakin tinggi peringkat diferensiasi fungsional, maka sekularisasi akan semakin bertambah-tambahini berarti agama akan pertama-tama kehilangan atau berkurang dampaknya terhadap penentuan aturan-aturan yang mengatur domain-domain kelembagaan yang berbeda-beda. Dengan kata lain, aturan-aturan keagamaan tradisional, atau norma-norma yang didasarkan pada nilai-nilai keagamaan, akan semakin digantikan oleh norma-norma sekuler atau betul-betul tersingkir, menjadi tidak dapat dipakai di dalam subsistem-subsistem pendidikan, keluarga, politik, ekonomi, dan sains, yang berbeda-beda."

Menurut Cornelis Van Peursen, sebagaimana dikutip Harvey Cox, mendefinisikan sekularisasi sebagai "pembebasan

sekularisasi, telah dipertahankan sebelumnya oleh Émile Durkheim, The Elementary Forms of the Religious Life (New York: Free Press, 1995). 
manusia” pertama-tama dari agama dan dari persoalan metafisika yang mengatur nalar dan bahasanya, yang berarti "terlepasnya dunia dari pengertian-pengertian religius semu, terhalaunya semua pandangan-pandangan dunia yang tertutup, terpatahkannya semua mitossupranaturaldanlambang-lambangsuci...'defatalisasi sejarah', penemuan manusia akan kenyataan bahwa ia tinggalkan dengan dunia di tangannya, sehingga ia tidak bisa lagi menyalahkan nasib atau kemalangan atas apa yang ia perbuat dengannya...; manusialah yang mengalihkan perhatiannya lepas dari dunia-dunia di atas sana ke arah dunia sini dan waktu kini. ${ }^{15}$ Artinya sekularisasi merupakan sesuatu yang merujuk pada arah perubahan dan penggantian halhal yang bersifat adikodrati dan teologis menjadi hal-hal yang bersifat alamiyah dalam bingkai dunia ilmu pengetahuan yang serba ilmiah dan argumentatif. ${ }^{16}$ Atau lenyapnya penentuan religius dalam lambang-lambang integrasi kultural, suatu proses historis di mana masyarakat dan budaya terbebas dari perwalian pengaturanpengaturan religius dan pandangan-pandangan dunia metafisis yang tertutup. ${ }^{17}$

Sekularisasi merupakan proses yang mengisyaratkan kepada pengertian pembebasan masyarakat dari belenggu tahayul dalam beberapa aspek kehidupannya, namun ini tidak berarti penghapusan orientasi keagamaan dalam norma-norma dan nilainilai kemasyarakatan tersebut. ${ }^{18}$ Sekularisasi lebih merupakjan suatu bentuk evolusi sosio-kultural dalam arah pemilahan fungsional, dari konsekuensi transformasi masyarakat di mana sistem agama tidak lagi secara primer diorientasikan sebagai masyarakat kepada

${ }^{15}$ Ibid. h. 20.

${ }^{16}$ Lihat Pardoyo, Sekularisasi Dalam Polemik, (Jakarta: Pustaka Utama, 1993), h. 82. Namun demikian sekularisasi haruslah dibedakan dengan sekularisme. Sekularisasi dalam perkembangan isme-isme merupakan sebuah sistem pemikiran yang terbuka, sementara pada sekularisme bersifat ideologis karena ia lebih tertutup dengan pemutlakan pada nilai-nilai yang dianggapnya telah final. Sekularisme pertama kali diperkenalkan oleh George Jacob Holyoake pada tahun 1846, menurutnya sekularisme adalah suatu sistem etik yang didasarkan pada prinsip moral alamiah dan terlepas dari agama wahyu atau supranaturalisme. Lihat Grolier International, dalam Encyclopedia Americana, Vol. 24, 1980, h. 521.

${ }^{17}$ Syed Muhammad an-Naquib al-Attas, Islam dan Sekularisme...h. 20

${ }^{18}$ Nurcholish Madjid, Islam Kemodernan dan Ke-Indonesiaan, (Bandung: Mizan, 1994), h. 254 
lingkungan sistem sosial personil, tetapi sebagai sub sistem masyarakat yang diorientasikan pada lingkungan sosial internal. ${ }^{19}$

Terdapat tiga komponen integral dalam dimensi sekularisasi, yaitu: pertama, penidak keramatan alam, yaitu suatu bentuk sikap dari pembebasan alam dari nada-nada keagamaan yang tidak pada tempatnya, sehingga tidak lagi memandang alam sebagai suatu wujud yang di dewa-dewakan, sehingga secara otomatis memberi peluang bagi manusia untuk memanfaatkannya menurut kebutuhan-kebutuhan dan rencana-rencananya yang dapat menciptakan perubahan sejarah dan 'perkembangan'. Kedua, desakralisasi politik, yaitu penghapusan ligitimasi sakral kekuasaan politik, yang merupakan persyaratan perubahan politik dan juga perubahan sosial yangmemungkinkan terjadinya proses sejarah. ${ }^{20}$ Ketiga, dekonsekrasi nilai-nilai, yaitu pemberian makna sementara dan relatif kepada bentuk perwujudan karya budaya dan setiap sistem nilai termasuk agama serta pandangan-pandangan hidup yang bermakna mutlak dan final untuk membuka ruan terbuka bagi perubahan yang bersifat evolusioner. ${ }^{21}$

Dengan melihat tiga komponen tersebut para pendukung sekularisasi pada wilayah agama cenderung melihat pentingnya sekularisasi sebagai sikap baru dalam memahami dan memposisikan agama. Sikap terhadap nilai-ilai ini menuntut kesadaran akan kenisbian pandangan tertentu dan kepercayaannya; yang menekankan kesadaran bahwa aturan-aturan dan kodekode etik perilaku tentunya akan mengalami perubahan sesuai dengan perkembangan waktu dan generasi. Sikap ini menuntut evolusi kesadaran manusia menuju kedewasaan yang terjadi pada

${ }_{19}$ Bassam Tibi, The Crisis of Modern Islam, terj. Yudian W. Asmin, dkk, (Yogyakarta: Tiara Wacana, 1994), h. 168-169.

${ }^{20}$ Dalam konteks Islam, Bruce M. Bortwick melakukan penelitian terhadap fungsi politik ulama dan menyimpulkan bahwa dalam sistem organik agama Islam tradisional fungsi agama dan fungsi politik digabungkan dan diselenggarakan oleh strukturyang sama.... institusi-institusi dan jabatan keagamaan benar-benar menjadi bagian dari negara sebagaimana halnya angkatan bersenjata dan para jenderal... ulama-ulama Sunni diharapkan mendakwahkan ketaatan kepada penguasa. Ibid., h. 171. Lihat juga dalam Jhon L. Esposito (ed), Identitas Islam Pada Perubahan Sosial Politik, terj. A. Rahman Zainuddin, (Jakarta: Bulan Bintang, 1986), h. 88-93.

${ }^{21}$ Syed Muhammad an-Naquib al-Attas, Islam dan Sekularisme...h. 21-22. 
'persilangan gerak sejarah atas manusia dan tindakan manusia atas sejarah'.22

Secara historis, kemunculan sekularisme berawal dari sejarah gerakan pemikiran Kristen modern pada abad tujuh belas dan delapan belas yang kemudian dikenal sebagai masa Pencerahan (Enlightenment). Dalam bidang pemikiran, Pencerahan ini ditandai sebagai era pemikiran modern dari Novum Organum Francis Bacon (1620) sampai ke Critique of Pure Reason Immanuel Kant (1781). Pencerahan ini kemudian berdampak pada perubahan paradigma pandangan hidup modern dengan pandangan hidup zaman pertengahan. Hal ini kemudian mendorong para teolog Kristiani untuk menafsirkan kembali dogma-dogma agama Kristen agar tetap relevan dengan perkembangan kehidupan masyarakat modern. Sebagaimana yang dilakukan oleh para teolog Eropa dan Amerika seperti Ludwig Feurbach (1804-1872), Karl Barth (1886-1968), Dietrich Bonhoeffer (1906-1945), Paul van Buren, Thomas Altizer, Gabriel Vahanian, William Hamilton, Woolwich, Werner and Lotte Pelz, dan beberapa lainnya. Upaya-upaya yang dilakukan oleh beberapa tokoh tersebut pada gilirannya melahirkan revolusi teologi yang cukup radikal. Mereka dikenal sebagai para "teolog kematian Tuhan" (death-of God theologians).

Para pemikir di atas menegaskan bahwa untuk menghadapi sekularisasi, ajaran Kristiani harus disesuaikan dengan pandangan hidup sains modern. ${ }^{23}$ Mereka membuat penafsiran baru terhadap Bible dengan menggunakan pendekatan baru, khususnya filsafat. Mereka menolak penafsiran lama yang menyatakan bahwa ada alam lain yang lebih hebat dan lebih agamis dari alam ini. Penafsiran baru ini juga membantah peran dan sikap Gerejawan yang mengklaim bahwa Gereja memiliki keistimewaan sosial, kekuatan, dan properti khusus. Penafsiran atau teologi baru inilah yang kemudian dirangkai menjadi teologi sekular; yang mengkritik posisi Gereja dengan teologi lamanya yang dianggap ideal. Khususnya, pada saat institusi Gereja memiliki kekuasaan dan peran sentral pada abad pertengahan Eropa. ${ }^{24}$

\section{${ }^{22}$ Ibid.,}

${ }^{23}$ John William Draper, History of The Conflict Between Religion and Science, (Princeton: Temple of Earth Publisshing, tt), h. 11-12.

${ }^{24}$ Harvey Cox, 'Why Christianity Must Be Secularized" in The Great Ideas 
Ludwig Feurbach (1804-1872), beranggapan bahwa prinsip filsafat bukanlah substansi-nya Spinoza, atau ego-nya Kant dan Fichte, bukan juga identitas absolut-nya Schelling, bukan juga akal absolut-nya Hegel, bukan pula konsep wujud yang abstrak, tetapi realitas wujud yang benar, yaitu manusia. Lebih lanjut Feurbach menegaskan bahwa manusia merupakan prinsip filsafat yang paling tinggi. Sekalipun agama atau teologi menyangkal, namun pada hakikatnya, agamalah yang menyembah manusia (religion that worships man). Agama sendiri yang menyatakan tuhan adalah manusia dan manusia adalah tuhan (God is man, man is God). Jadi, agama akan menafikan Tuhan yang bukan manusia. Sehingga makna teologi yang sebenarnya adalah antropologi (The true sense of Theology is Anthropology). Agama adalah mimpi akal manusia (Religion is the dream of human mind) ${ }^{25}$ Pemikiran Feurbach semacam ini memiliki pengaruh cukup besar terhadap pemikiran para sosiolog dan teolog setelahnya seperti Friedrich Gogarten (1887-1967), Karl Barth, Martin Buber dan Karl Marx.

Dalam buku yang berjudul Verhängnis und Hoffnung der Neuzeit: die Säkularisierung als theologisches Problem (Nasib dan Harapan Zaman Kita: Sekularisasi sebagai sebuah Masalah Teologis; Stuttgart, 1958), Friedrich Gogarten (1887-1967), seorang teolog Protestan mengatakan:

Secularization in our day is reaching its climax, and yet our thinking about it still arises from assumptions which either know nothing about this secularization or else have a false conception of what has taken place in it and where its foundations lie. We can obviously only learn from it what must be learnt here if we understand that secularizarion regardless of what may have developed from it in modern times, is a legitimate consequence of the Christian faith. (penekanan ditambah). ${ }^{26}$

Sebagaimana Gogarten, Karl Barth dan muridnya Dietrich Bonhoeffer juga menegaskan bahwa "agama sebagai ketidakpercayaan" (Religion as Unbelief). Bonhoeffer menyeru para teolog Kristen supaya menyampaikan risalah Kristiani dengan konsep sekuler. Menurutnya agama harus dipisahkan dari

Today 1967, (Chicago: Encyclopaedia Britannica, Inc, 1967), h. 9-10.

${ }^{25}$ Ludwig Furbach, The Essence of Christianity, penerjemah George Eliot (New York: Prometheus Books, 1989), h. xiii-xix.

${ }^{26}$ Cox, The Great..., h. 11. 
kepercayaan (faith). Dia selanjutnya mengatakan dengan frasenya yang paradoks: "sudah tiba saatnya bagi Kristen tanpa agama" ( $a$ religionsless Christianity).

Tokoh lain yang seirama dengan pandangan di atas adalah Gabriel Vahanian, seorang Teolog Neo-Calvinis. Dalam hal ini ia mengatakan: "sekular adalah keharusan seorang Kristiani". Menurutnya, kematian Tuhan adalah peristiwa agama dan sekaligus budaya. Oleh karena itu peristiwa-peristiwa dalam Bible dianggap sebagai mitos, sudah lapuk, dan tidak terpakai lagi. Bahkan pernyataan lebih ekstrim muncul dari Werner and Lotte Pelz yang mendeklarasikan "Tuhan tiada lagi" (God is no more), dalam judul sebuah buku mereka yang diterbitkan pada tahun 1963. Demikian juga pendeta Woolwich dengan nada yang sama juga berpendapat bahwa "Tuhan tanpa Tuhan" (God without God) sebagaimana dalam bukunya Honest to God (Jujur kepada Tuhan).

Jika dibaca secara dangkal, pemikiran para tokoh di atas seolah-olah mengarah pada paham atheis. Namun demikian pada kenyataannya mereka masih mempercayai wujudnya Tuhan. Dalam hal ini mereka hanya berusaha mengkritisi fenomena yang terjadi pada masyarakat modern, di mana tuhan sudah tidak berperan lagi dalam kehidupan masyarakat (Kristen). Tuhan diposisikan di luar urusan kehidupan manusia. Tuhan tidak berhak campur tangan dalam kehidupan manusia. Manusia harus mengatur hidupnya sendiri dengan hukum-hukum yang mereka buat sendiri.

Paradoks pemikiran teologi konservatif dan teologi radikal kemudian dipertemukan oleh Harvey Cox dengan teologi sekularnya. Dalam hal ini Cox mengkritik pendapat para teolog kematian Tuhan, karena mereka dianggap keliru dalam dua hal. Pertama, mereka telah menjadikan pandangan hidup saintifik modern sebagai parameter, padahal humanisme saintifis modern itu beraneka-ragam. Selain itu, para saintis pun mengakui bahwa metodologi saintifik bersifat operasional dan berada dalam ruang lingkup yang terbatas. Oleh sebab itu, metodologi saintifik tidak menawarkan "pandangan hidup'. Kedua, pendapat teolog radikal terhadap teologi Kristen tidak kritis dan ahistoris. Mereka menganggap isi doktrin Kristen tidak berubah, maka perlu dibuang. ${ }^{27}$

${ }^{27}$ Ibid., h. 12. 


\section{Secular City: Mengupayakan Teologi Perubahan Sosial}

Dalam tradisi Kristen, gereja pada dasarnya merupakan respon masyarakat yang bertugas melihat perbuatan Tuhan di Dunia, dan bergabung dalam Karya-Nya itu. Perbuatan Tuhan terjadi dalam "peristiwa-peristiwa historis", atau lebih tepatnya melalui "perubahan-perubahan sosial". Dengan demikian gereja harus selalu memberi jawaban terhadap perubahan sosial tersebut. Namun dalam realitas sejarah, gereja senantiasa terhambat oleh doktrin-doktrin yang diwarisi dari zaman kekristenan kuno, dan terpengaruh oleh ideologi "pemeliharaan" dan "ketetapan". Doktrindoktrin yangberorientasi pada masa lampau telah memberikan otoritas dari periode klasik atau dari teori kelangsungan sejarah (historical continuity).

Dalam pandangan Cox, ummat Kristen mendapati diri mereka telah dijalari oleh meledaknya fermentasi sosial. Dengan gigih mereka sedang mencari perspektif teologis yang bisa memahami keadaan mereka. Namun persoalan mereka itu sangat sedikit sekali diselesaikan oleh Gereja Kristiani. Kita sedang berusaha untuk hidup dalam zaman yang cepat berubah dengan menggunakan teologi yang statis. Oleh karena itu, Cox berpendapat bahwa agenda pertama yang harus dilakukan adalah menemukan sebuah teologi yangs esuai dengan tuntutan ummat saat ini. ${ }^{28}$

Lebih lanjut Cox menilai bahwa teologi yang dibutuhkan bukanlah teologi sejarah (theology of history) - sebagaimana yang sedang diupayakan oleh para teolog - karena istilah teologi sejarah bisa menimbulkan kesalah pahaman. Bagi kebanyakan orang, sejarah menunjuk pada masa lampau sehingga menutup realitas kekinian..$^{29}$ Oleh karena itu, menurut Cox, yang diperlukan adalah sebuah teologi baru yang sesuai dengan perubahan masyarakat, yaitu teologi perubahan sosial (teology of social change). ${ }^{30}$

Sebagai dasar teologi perubahan sosial tersebut, Cox menggunakan simbol-simbol kehidupan yang ditunjukkan oleh Kota Sekuler (secular city). Menurutnya, ide tentang kota sekuler mampu

${ }^{28}$ Harvey Cox, The Secular City, (New York: McaMillan Company, 1965), h. 107.

${ }^{29}$ Ibid.

${ }^{30}$ Ibid., h. 105. 
memberikan kontribusi penting dalam memahami apa yang dalam Perjanjian Baru disebut sebagai "Kerajaan Tuhan" (The Kingdom of God), serta untuk mengembangkan sebuah teologi yang dapat hidup yang muncul dari perubahan sosial yang revolusioner. Dalam Kristologi, simbol Kerajaan Tuhan terwujud dalam Jesus. Dalam hal ini Cox mengutip pendapat Amos Wilder yang mengatakan bahwa Jesus mengidentikkan diri-Nya dengan Kerajaan Tuhan, sehingga makna kerajaan itu dihadirkan dalam diri-Nya. Jesus adalah wakil penubuhan serta tanda pokok Kerajaan Tuhan. ${ }^{31}$

Ketika Jesus dipersonifikasikan sebagai Kerajaan Tuhan, maka unsur inisiatif ketuhanan dan respon menusia merupakan dua hal yang tidak bisa dipisahkan dalam Kerajaan Tuhan tersebut. Jika hal ini diterjemahkan ke dalam perubahan sosial, maka sejarah bukan hanya merupakan sesuatu yang terjadi terhadap manusia, namuns ekaligus yang dilakukan manusia. Dengan demikian Kota Sekuler merupakan titik temu dari gerak sosial dan inisiatif manusia.

Kerajaan Tuhan yang dipusatkan pada hidup Jesus merupakan pengungkapan yang paling sempurna dari persekutuan antara Tuhan dan manusia dalam sejarah. Kedatangan Kerajaan Tuhan itu mewujud dalam bentuk tuntutan-tuntutan yang menuntut pembaharuan dalam beberapa hal, dan menerima sesuatu disiplin pada waktu yang lain. Cara hidup demikian menuntut adanya pemutusan secara radikal terhadap masa lampau, yang disebut sebagai "pertobatan". Oleh karena itu, Kerajaan Jesus akan hadir ketika perbuatan Tuhan (yang baru) menyatu dengan perbuatanperbuatan manusia untuk menyisihkan nilai-nilai dan loyalitas yang lama, dan dengan bebas memasuki realitas yang baru.

Dengan demikian, munculnya kota sekuler sekaligus sebagai kritik terhadap Gereja yang senantiasa gagal dalam menghadapi persoalan ummatnya di tengah kehidupan modern. Dalam perspektif ini, gereja tidak dilihat sebagai sebuah lembaga, melainkan sebagai ummat Tuhan, ummat yang lembaganya harus ikut serta dalam membebaskan manusia kepada kebebasan dan tanggungjawab. Oleh karena itu, gereja memiliki beberapa fungsi: (1) memproklamasikan kedatangan tatanan hidup baru (kerygma);

${ }^{31}$ Ibid., h. 111. 
(2) mempersonifikasikan arti tatanan hidup baru (diakonia); dan (3) mulai membagi-bagikan berkatnya (koinonia).

Kerygma berfungsi menyadarkan manusia agar benar-benar terbebas dari ketergantungannya kepada nasib, dan mengakui bahwa hidupnya itu merupakan hidup yang baru, yang diletakkan di tangannya sendiri. Dalam pengertian ini manusia tidak boleh menyalahkan kekuasaan-kekuasaan ekonomi ataupun tekanan psikologis bagi ketidak adilan sosial. Manusia dipanggil untuk menjinakkan kuasa-kuasa itu supaya seluruh alam semesta menjadi tempat tinggal manusia yang menyenangkan. ${ }^{32}$

Diakonia, menunjuk pada perbuatan penyembuhan dan perdamaian. Jika diterapkan dalam kehidupan kota sekuler, maka tanggungjawab Gereja adalah melaksanakan "pelayanan komunikasi” yang efektif. Dalam konteks ini Gereja dituntut untuk bisa mengatasi persoalan-persoalan yang timbul dalam masyarakat. ${ }^{33}$

Koinonia, menunjuk pada tanggungjawab Gereja dalam kota sekuler, yang memanggilnya untuk mendemonstrasikan secara nyata apa yang dinyatakan dalam kerygma dan diakonia. Dengan demikian Gereja menjadi kota manusia yang unggul dan menjadi pelopor dalam kehidupan kota sekuler. ${ }^{34}$

\section{E. Wajah Tuhan dalam Masyarakat Sekuler}

Perbincangan tentang "wajahTuhan" secara sekulerbukanlah semata-mata merupakan problem sosiologis an sich, melainkan termasuk problem politik sekaligus. Karena problem ketuhanan ini akan selalu menjadi tuntutan yang menyertai kehidupan manusia dan dinamika yang ada di dalamnya berupa konflik-konflik yang terjadi serta upaya mendapatkan kemerdekaan seseorang. Tetapi pembicaraan Tuhan dalam perspektif sosiologi dan politik akan menjadi sesuatu yang melelahkan, meski disampaikan oleh teolog modern sekalipun.

Dalam konteks ini, ada tiga cara untuk menjelaskan "wajah Tuhan” bagi masyarakat sekuler, yaitu: (1) Tuhan sebagai problem

\footnotetext{
${ }^{32}$ Ibid., h. 121-131.

${ }^{33}$ Ibid., h. 132-143.

${ }^{34}$ Ibid., h. 144-148.
} 
sosiologis; (2) Tuhan sebagai problem politis; dan (3) Tuhan sebagai problem teologis.

Tuhan sebagai problem sosiologis tidak hanya muncul dalam anggapan tentang Tuhan saja, melainkan juga dalam penggunaan kata "Tuhan" itu sendiri, yang dalam banyak hal sering tidak tegas dalam memposisikan diri. Ketidaktegasan ini lebih dikarenakan (a) perubahan-perubahan historis dan (b) jarak-jarak sosial yang ada. Perubahan historis dimaksudkan karena adanya perbedaan konotasi pada masing-masing fase sejarah, sementara kedua lebih disebabkan adanya kompleksitas masyarakat itu sendiri. Misalnya, kata-kata yang sama akan memiliki arti yang berbeda bila diucapkan dalam setting masyarakat yang berbeda.

Hal ini menjadi persoalan cukup serius ketika problem historis ini menyatu dalam diferensi sosial yang ada. Karena perubahan suatu masyarakat (apapun bentuknya) akan mengubah semua kandungan makna bahasa yang digunakan. Oleh karena itu menurut Antoni Meillet (pakar sosiolog dari Prancis), penemuan struktur masyarakat, berikut bahasa-bahasa yang digunakan adalah merupakan suatu yang esensi. ${ }^{35}$

Secara historis, kata "Tuhan“ (God) sudah ada jauh sebelum Kristen lahir, yang sering digunakan dalam terjemahan-terjemahan yang berbeda, seperti theos-nya filsuf Yunani, Deus-nya ahli Metafisika Barat, Yahweh dalam Bible Yahudi dan sebagainya. Dan secara sosiologis, penggunaan ini sah karena memang bahasa (kata) itulah yang sesuai dengan konteks zamannya (sama seperti pengeran-nya orang Jawa). Pendek kata masalah kata "Tuhan" dalam tradisi (bahasa) maupun sosiologi modern lebih merupakan problem linguistik (sosiologi linguistik).

Sementara Tuhan sebagai problem politis, muncul sebagai akibat langsung dari problem sosiologis yang menyertainya. Kalau kebanyakan teolog tetap menempatkan problem "Tuhan dalam bayangan" ini sebagai problem "kebahasaan historis", maka lain halnya dengan Van Peursen, ia lebih menganggap sebagaimana halnya dengan cakupan metafisisnya dalam Bible (Tuhan dalam Bible), kata Tuhan haruslah pula dimaknai sebagai terminologi

${ }^{35}$ Talcott Parson, Theories of Personality, (Glencoe: The Free Press, 1961), h. 108. 
sejarah. Sejalan dengan Peursen tersebut, Carl Michalson (seorang teolog Amerika) sependapat ketika Tuhan secara metafisis tidak membutuhkan pemaknaan sejarah, karena menurutnya, pemaknaan Bible inhern dalam proses kesejarahannya sendiri, bukan dalam "wujud" kesejarahannya. ${ }^{36}$

Walaupun pada akhirnya pendapat Peursen dan Michalson ini diyakini kebenarnnya dan relatif diterima, namun ketika dikatakan bahwa teologi pada akhirnya harus historis (dan bukan sekedar metafisis), maka akan menjadi sulit untuk dipahami sekaligus kontraproduktif dengan perbincangan soal "teologi dalam perubahan sosial". Dari sinilah kemudian persoalan politis mulai muncul. Hal ini terjadi karena kata historis bagi kebanyakan lebih cenderung dimaknai sebagai "masa lampau", sehingga teologi dalam masyarakat yang berubah, teologi historis atau teologi masa lampau ini kurang meminkan perannya, lebih-lebih teologi metafisis yang kering dengan nilai-nilai historis.

Hanya saja pemakaian term politis ini mengalami pencairan ketika ia mulai dimaknai secara luas, sebagaimana yang dilakukan JBM. Miller dalam bukunya Nature of Politic, di mana ia lebih merupakan produk yang dihasilkan oleh adanya konflik dan perbedaan-perbedaan kelas dalam masyarakat. Sejauh konflik dan kesenjangan sosial itu dapat dieliminir, maka bahaya akan perpecahan itu hilang dengan sendirinya.

Pemaknaan Tuhan dalam persoalan-persoalan politik pada perkembangan berikutnya, juga tampak dalam kesatuan kerja (kerjasama) antara Tuhan dan manusia, di mana kerja manusia adalah sekaligus kerja Tuhan. Demikian pula sebaliknya. Sehingga klaim-klaim "kebersamaan dengan Tuhan" dalam karya ini jugalah yang kemudian menjadi klaim kelompok tertentu untuk mencari legitimasi politik dalam menjalankan kegiatan keagamaannya.

Tuhan sebagai problem teologis muncul dalam suasana teologis saat ini, di mana para teolog tidak lagi memposisikan "Tuhan" dalam tradisi masyarakat tertentu, namun mereka mulai mengakui adanya perbedaan cara manusia dalam mempersepsikan

${ }^{36}$ Dalam James Robinson, The Late Heidegger and Theology, (New York: Harper, 1963), h. 147. 
“Tuhan”. Dalam situasi teologis yang demikian, muncul kesamaankesamaan pokok antara keimanan Bible dan Ateisme. Fenomena semacam ini sangat dimungkinkan mengingat doktrin Bible tentang "ketersembunyian Tuhan" (deus absconditus) bisa mengarah pada ateisme atau non-teisme saat ini.

Ketersembunyian Tuhan Bible merupakan inti dari doktrin tentang Tuhan. Namun di balik ketersembunyian Tuhan itu mengisyaratkan kebebasan Tuhan menampakkan dirinya pada masing-masing agama, dengan cara yang dipilihnya sendiri. Sehingga penampakan Tuhan tidak terikat oleh kriteria-kriteria sebagaimana yang dibuat dan diinginkan oleh manusia. Ia menyembunyikan dirinya dalam pengertian bahwa kita hanya menyebutkan, menunjukkan bahwa ia bukanlah sesuatu seperti apa yang diinginkan agama-agama atau yang mereka harapkan dari Tuhan mereka. Maka ketersembunyian Tuhan inilah yang membedakannya dengan (Tuhan) yang lainnya. Ia bersembunyi dari persepsi manusia, namun nampak dalam realitas sejarah manusia.

Dengan menggunakan pola pikir di atas, maka perbedaan antara keimanan bible dan non-teis bukanlah pada realitas Tuhan, namun lebih pada penamaan yang berbeda atas realitas itu. Maka benarlah ketika Paul M. Van Buren mengatakan bahwa problem kita saat ini muncul dari kesulitas penggunaan bahasa agama tradisional.

\section{F. Penutup}

Menyimak pemikiran Harvey Cox, nampak bahwa ia ingin menyadarkan Gereja Kristiani - juga agama lain - bahwa sekularisasi merupakan sebuah keniscayaan sejarah. Dalam kerangka ini berbeda dengan kebanyakan teolog yang menghawatirkan implikasi sekularisasi, Cox justru melihatnya dalam kaca mata positif. Sehingga ia bisa digunakan sebagai sebuah gerakan yang membebaskan manusia dari dogma yang membelenggu kebebasan kreatifitas manusia. Dengan menggunakan simbol kota sekuler, Cox berusaha menghadirkan paradima teologi baru yang - menurutnya - lebih sesuai dengan keadaan masyarakat modern saat ini.

Namun satu hal yang lebih penting, Cox telah menunjukkan bahwa Tuhan sebagaimana yang diajarkan oleh Kristiani - juga 
agama lain - bukanlah Tuhan yang sebenarnya. Tuhan tak lebih sebuah penamaan yang kehadirannya terkadang kosong dan ambigu. Semenjak penamaan yang menjadi aktifitas kemanusiaan dilekatkan dalam lingkungan sosio kultural tertentu, maka kata "Tuhan" tidak suci lagi. Hal ini mengingatkan kita pada kenyataan bahwa ketika Tuhan yang semula kosong itu dimaknai secara "ketat" dalam ruang tradisi yang berbeda-beda, maka akan terjadi benturan-benturan yang terkadang membutuhkan pengorbanan jiwa. Jika bukti ketaatan masyarakat Tribal (kesukuan) pada Tuhannya dibuktikan dengan sesembahan - sesaji, mungkinkan kita akan mempersembahkan nyawa sebagai bukti ketaatan kita pada Tuhan? []

\section{Daftar Pustaka}

Al-Attas, Syed Muhammad an-Naquib, Islam dan Sekularisme, Bandung: Penerbit Pustaka, 1981.

Amstrong, Karen, Sejarah Tuhan, terj, Bandung: Mizan, 2001.

Berger, Peter L., The Sacred Canopy: Elements of a Sociological Theory of Religion (New York: Doubleday \& Company, 1969)

Cox, Harvey, 'Why Christianity Must Be Secularized" in The Great Ideas Today 1967, Chicago: Encyclopaedia Britannica, Inc, 1967. , The Secular City, New York: McaMillan Company, 1965.

Draper, John William, History of The Conflict Between Religion and Science, Princeton: Temple of Earth Publisshing, tt.

Esposito, Jhon L. (ed), Identitas Islam Pada Perubahan Sosial Politik, terj. A. Rahman Zainuddin, Jakarta: Bulan Bintang, 1986.

Furbach, Ludwig, The Essence of Christianity, penerjemah George Eliot, New York: Prometheus Books, 1989.

Grolier International, dalam Encyclopedia Americana, Vol. 24, 1980.

Hadden, Jeffrey K., \& Shupe, Anson (eds.), Secularization and Fundamentalism Reconsidered: Religion and the Political Order (New York: Paragon House, 1989)

Hadiwijono, Harun, Teologi Reformatoris Abad ke-20, Jakarta: Gubug Mulia, 1993. 
Hassan, Fuad, Pengantar Filsafat Barat, Jakarta: Dunia Pustaka, 1996

Lexicon Universal Encyclopedia, New York: Lexicon Publication, 1990.

Madjid, Nurcholish, Islam Kemodernan dan Ke-Indonesiaan, Bandung: Mizan, 1994.

Pardoyo, Sekularisasi Dalam Polemik, Jakarta: Pustaka Utama, 1993.

Parson, Talcott, Theories of Personality, Glencoe: The Free Press, 1961.

Robinson, James, The Late Heidegger and Theology, New York: Harper, 1963.

Siswomihardjo, Koento Wibisono, Ilmu Pengetahuan: Sebuah Sketsa Ilmu Mengenai Kelahiran dan Perkembangannya Sebagai Pengantar Untuk Memahami Filsafat Ilmu, Diktat Kuliah Filsafat Ilmu, Tidak diterbitkan.

Tibi, Bassam, The Crisis of Modern Islam, terj. Yudian W. Asmin, dkk, Yogyakarta: Tiara Wacana, 1994. 
Fauzan

halaman ini bukan sengaja dikosongkan 